\title{
3 Research Square \\ Unit Price of Manufacturing Exports that Process Natural Resources From Latin America.
}

\section{Gerardo Fujii-Gambero ( $\nabla$ fuji@@unam.mx )}

National Autonomous University of Mexico (UNAM) https://orcid.org/0000-0002-5668-9973

\section{Rodrigo Morales-López}

National Autonomous University of Mexico (UNAM)

\section{Research}

Keywords: World trade in natural resource-intensive manufactures, unit price of exports, natural resource value chains.

Posted Date: September 14th, 2021

DOl: https://doi.org/10.21203/rs.3.rs-850454/v1

License: (1) This work is licensed under a Creative Commons Attribution 4.0 International License. Read Full License 


\section{Abstract}

\section{Lead-in}

We explore the potential domestic income increase in Latin American exports following unit prices of exported products by processing stage.

In various developed countries, manufacturing began through the internal processing of locally available natural resources. Currently, high-income countries participate in world trade by exporting these types of products. The objective of this paper is to demonstrate the level of sophistication of these exports by monitoring the unit price of exports of the petrochemical chain (Argentina, Brazil, Mexico, and Venezuela); copper (Chile and Peru); iron and steel (Brazil and Mexico); and soybean and its derivatives (Argentina and Brazil). We show the potential for elevating domestic income in exports by increasing manufacturing done within a country before export.

JEL classification: F14, L61, L65, L66, L71, 013, Q17

\section{Introduction}

Latin American countries are important exporters of both primary products and manufactures that have undergone a process of transformation. Therefore, it is essential to study ways of improving the benefits these countries derive from participating in the world trade of manufactures.

The natural-resource value chain connects three phases: the first consists of preparatory activities for the exploitation of natural resources, followed by a study of the feasibility of exploitation, which includes project engineering and evaluation in terms of economic and environmental impacts. These stages are intensive in technological services. If the preliminary information is positive, the investment of fixed capital proceeds in agriculture, mining, or fishery. Products obtained thereof are processed by manufacturing. This transformation is simple for food crops and more complex for forest and mineral products. The value-adding process in these chains occurs in two phases: from resource exploration to exploitation, and from primary production to transformation into semi-fabricated and final products. In this paper we explore the second stage of value creation.

Different ways exist to improve the quality of a country's participation in the global value chain of natural resources. One way is to increase the domestic manufacturing of primary products. The second involves expanding the production of capital goods and inputs that require the exploitation and transformation of natural resources. The third is to promote companies that provide specialized technological services in these activities. These three alternatives can be strengthened with a view to exporting these products and services.

In Mexico, discussion regarding the insufficient domestic value added to the country's exports has focused on the high imported content of some important products contained in its export basket. Often 
overlooked, another way to increase this value is by strengthening domestic forward linkages between primary activities and the manufacturing that processes primary products, as well as between the manufacturing sectors that successively transform industrial products derived from natural resources. This is an ongoing discussion in South American countries.

The objective of this paper is more limited than the broad topics we have reviewed. We, first, discuss the importance of the industry that transforms natural resources in the development process of some economies and the current weight of this industry in world trade (section II). Second, we highlight the degree of production of manufactured exports that process natural resources in some Latin American countries (section III), which will shed light on the region's potential for increasing domestic income contained in exports. We analyze four export chains: petrochemicals in Argentina, Brazil, Mexico, and Venezuela; copper in Chile and Peru; iron and steel in Brazil and Mexico; and soybeans in Argentina and Brazil. In order to detect the level of sophistication of these exports and the opportunities open to the countries in the region, our analysis is based on the unit price of exported products by stage of production, comparing Latin American exports with those of other major world exporters of these products (section IV). Finally, in section IV we present our main conclusions in terms of industrial policy. The methods used in this research can be found in the Online Appendix A.1.

\section{li. Background}

1. Industrialization based on transforming natural resources

There are many critical opinions about the specialization of economies in the production and export of primary products. Adam Smith called it a lottery game with very little chance of winning (Smith 1977, 741-742). Prebisch's (1949) opinion that countries exporting primary products tend to grow more slowly than those specialized in industrial production is well known. Also, prices of these products experience significant fluctuations, which exacerbate the instability of these economies. Recently, the expression the "natural resource curse" has been used to refer to the fact that these economies tend to grow more slowly than those with a diversified export base (Sachs and Warner 1997 and 2001; Auty 2001), particularly the large oil exporters (Hausmann and Rigobon 2002); that such countries are more unequal (Higgins and Williamson 1999); or that they are prone to the "Dutch disease"; or that mining tends to be an enclave sector (Frischtak and Beluzzo 2014); or that these countries are prone to have socio-political and institutional characteristics that hinder balanced growth (Rosser 2006).

There are, however, several highly developed countries that achieved great economic success based on natural resources. Their example gave rise to the staple theory of economic development used as the basis for interpreting the evolution of economies characterized by great wealth and diversity in natural resources, i.e., Australia, Canada, and the United States (Altman 2003). These countries have moved from primary activities to the manufacturing transformation of these resources and the production of technological services for such activities. 
The fact that natural resource wealth does not necessarily condemn countries, but rather can be the basis for economic development, has been highlighted in research on the industrialization of Denmark, the Netherlands, Norway, Finland, Switzerland, and Sweden during the 20th century. These countries entered world trade through the export of primary products and then diversified their exports into manufacturing that transforms natural resources and the production of equipment and technological services for these industries (Berend and Ránki 1982; Senghaas 1985, 152; Blomström and Kokko 2007; Blomström and Meller 1991).

The United States and Canada also underwent this type of industrial evolution. According to Kindleberger (1962), while at the beginning of the 20th century more than $90 \%$ of their exports consisted of raw materials, in the 1940 s exports of final goods were $40 \%$ and those of semi-processed products $28 \%$.

Currently, the most representative rich countries exporting primary products and technology for these sectors are Australia, Norway, New Zealand and, to some degree, Canada. Presently, Australia is a leading country in mining technologies (Frischtak and Belluzzo 2014; Blomström and Kokko 2007; Blomström and Meller 1991; Maloney 2007; Wright and Czelusta 2007).

South America's wealth of natural resources and its export profile has encouraged discussion of a development strategy for countries in the region centered on the manufacturing transformation of natural resources (Ramos 1998). It has been argued that, compared to Asia, Latin America has a greater availability of natural resources and a lower abundance of labor resources (Wood and Berge 1997). Pérez (2010) argues that the region's advantages are not in manufactures that are fragmented by the production of parts and components that thereafter assembled (electronics, automobiles, clothing), but in the "process industries" that transform a natural raw material into increasingly sophisticated products (from steel, paper, and plastic to products derived from advances in materials, chemistry, and biology). Maloney (2007) stressed that technological innovation in the natural-resources sector is the key element for spurring development of countries rich in mineral resources.

2. Foreign trade in manufactures that process natural resources

This section is divided into two parts: The first identifies the products considered here as manufactures based on the transformation of natural resources; the second part analyzes the foreign trade of these types of manufactures in 19 countries, both large and small, developed and middle-income, including six Latin American countries.

\subsection{Identification of products based on the transformation of natural resources}

Lall (2000) classifies natural-resource-based manufacturing exports into two groups: products derived from agriculture and forestry and from other resources, basically minerals. The Standard International Trade Classification (SITC), Rev. 3, include food, beverages and tobacco, rubber, wood, pulp and paper, and some textiles in the first group. The second group comprises the metallurgical, non-metallic minerals, and chemical industries. Furthermore, Lall's category of low-tech manufactures includes products that 
transform a natural resource, but in which the design or engineering content is important. This group is subdivided into two: textiles, clothing, and footwear, and other products, which include paper goods, ceramics, glass, some iron and steel products, furniture, and plastic goods. The category of mediumtechnology manufactures (Lall) includes process industries that transform natural resources, have a high engineering component, and are capital-intensive. Among the products included are synthetic fibers, fertilizers, plastics, iron and steel, and pipes.

In this paper we use two concepts of natural resource-based manufacturing: In the narrow sense, which covers only those manufactures that Lall considers as such, and in the broad sense which, in addition to these, includes low-technology and medium-technology process-based manufactures.

\subsection{Foreign trade of primary products and manufactures processing natural resources}

Tables 1 and 2 illustrate the weight of primary exports and of manufactures that process natural resources in 19 countries, grouped into three categories. Table 1 groups 13 high income countries divided in two sets: four high-income countries where primary exports account for a very high proportion of total exports (Australia, Canada, New Zealand, and Norway; total primary exports USD billion 72.9; 102.3; 75.9; and 13.1, respectively) and a second set groups together eight high-income economies (United States, Germany, Finland, France, Italy, Sweden, Japan, and Korea) plus China. In these countries, the weight of exports of raw materials and of the manufactures that process them is notably lower than in the previous group, but still not negligible. Table 2 is made up of six Latin American countries (Argentina, Brazil, Chile, Colombia, Mexico, and Peru), in which the weight of relevant exports is similar to that of the countries in the first group.

In the first group of countries, the weight of primary exports ranges from a minimum of $27 \%$ in Canada to $70 \%$ in Norway. Adding manufactures that process natural resources in a narrow sense, the contribution to exports ranges from $46 \%$ in Canada, and from $70-80 \%$ in Australia, Norway, and New Zealand. When low-technology and process-manufacturing exports are added, the shares range from $59 \%$ in Canada to more than $79 \%$ in the other three countries in this group (Table 1). All these countries have surpluses in trade in primary products and in manufactures that process them in a narrow sense, except for Norway. Trade in low-tech manufactures and process-based products posts negative balances in all countries in the group. However, the surplus in trade in primary products and resource-based manufactures in the narrow sense exceeds the deficit caused by trade in low-tech and process-based products.

Turning our attention to the high-income countries plus China, all net importers of primary products, the weight of primary exports in the total is significant only in the United States (10\%; USD 120.7 billion), but in absolute terms it is also important in Germany, China, and France. The importance of trade in manufactures that process natural resources in the narrow sense is rather more relevant, ranging from $9 \%$ in Japan to $33 \%$ in Finland. Adding these two product categories together, the weight in total exports is $38 \%$ in Finland, and between $20 \%$ and $30 \%$ in the United States, France, Italy, and Sweden. Adding lowtech and in-process exports, the weight of natural resource-based manufactured exports in the broad sense in total exports is $27 \%$ in Japan, between $30 \%$ and $40 \%$ in Germany and Korea, between $40 \%$ and 
$50 \%$ in the United States, France, and Sweden, and more than $50 \%$ in Italy and Finland. The data for China are as follows: The most relevant exports are those of low-technology manufactures $(31 \%$ of the total), followed by those of manufactures that process natural resources in a narrow sense and those of processes ( $8.1 \%$ and $5.2 \%$, respectively). All these countries post deficits in trade in primary products and the United States, China, Germany, Japan, Korea, and France also show deficits in trade in manufactures that process natural resources in the narrow sense, while Italy, Finland, and Sweden have surpluses. In trade in process manufactures, the United States, Germany, France, Japan, and Korea are in surplus, while Finland, Italy, Sweden and China are in deficit. Of all these countries, only in China does the surplus in trade in low-tech manufactures exceed the deficit in trade in primary products.

Table 1. Export composition of high-income countries (average 2005, 2010, 2016; percentages).

\begin{tabular}{|c|c|c|c|c|c|c|c|c|c|c|c|c|c|}
\hline & \multicolumn{4}{|c|}{ High primary exports } & \multicolumn{9}{|c|}{ Low primary exports } \\
\hline & AUS & CAN & NOR & NZL & USA & GER & JPN & KOR & FRA & ITA & FIN & SWE & $\mathrm{CHN}$ \\
\hline Primary products & 43.1 & 27 & 70.3 & 45.4 & 10 & 4.9 & 1.9 & 2.4 & 7.5 & 4.5 & 5.3 & 4.9 & 3.4 \\
\hline Manufactures that process natural resources (broad concept) & 36.3 & 31.8 & 13.4 & 40.6 & 32.9 & 32.3 & 25.4 & 32.3 & 39.2 & 48.6 & 50 & 41.5 & 43.8 \\
\hline Based on natural resources (narrow concept) & 32.4 & 19 & 8.4 & 32.7 & 15.8 & 11.4 & 8.5 & 12.6 & 15.8 & 15.2 & 32.6 & 22 & 8.1 \\
\hline In agricultural resources & 3.9 & 10.9 & 2.6 & 28.3 & 5.1 & 6 & 2.5 & 2.7 & 9.5 & 7.8 & 22.3 & 13.3 & 3.2 \\
\hline In other resources & 28.5 & 8.1 & 5.8 & 4.3 & 10.7 & 5.4 & 6 & 9.8 & 6.3 & 7.3 & 10.3 & 8.7 & 4.9 \\
\hline Low-tech manufacturing & 2.3 & 6.9 & 2.5 & 5.5 & 8.5 & 12.1 & 8.4 & 10.5 & 13.7 & 25.2 & 10.1 & 13.2 & 30.5 \\
\hline Process-based medium-technology manufacturing & 1.5 & 5.8 & 2.4 & 2.4 & 8.6 & 8.9 & 8.5 & 9.2 & 9.7 & 8.3 & 7.3 & 6.3 & 5.2 \\
\hline Other (medium technology, high technology, and unclassified) & 20.6 & 41.2 & 16.3 & 14 & 57.1 & 62.8 & 72.7 & 65.3 & 53.3 & 46.9 & 44.7 & 53.6 & 52.8 \\
\hline Total & 100 & 100 & 100 & 100 & 100 & 100 & 100 & 100 & 100 & 100 & 100 & 100 & 100 \\
\hline
\end{tabular}

Source: Prepared by the authors based on data from UNCTAD (2020).

Within the group of Latin American countries, Mexico is notably different from the rest. In the South American countries, the contribution of primary exports to the total ranges from $31 \%$ in Brazil to $57 \%$ in Colombia, while in Mexico it amounts to $14 \%$. Adding manufactures that process natural resources in a narrow sense, the percentages range from $62 \%$ in Brazil to $90 \%$ in Chile, while in Mexico it is $22 \%$. When low technology and process manufactures are added, the percentages range from $77 \%$ in Brazil to $96 \%$ in Chile. In Mexico, it is $36 \%$ (Table 2). All these countries have trade surpluses in primary products. For Argentina, Brazil, Chile, and Peru, trade in manufactures that process natural resources in a narrow sense yields a surplus, while for Colombia and Mexico it produces a deficit. For Mexico, the deficit in this trade exceeds the surplus in trade in primary products. Except for Brazil, all the other countries have a deficit in trade in low-technology manufactures. Finally, all Latin American countries record deficits in the trade of products in process. The combined trade balance for all these products is in surplus in Argentina, Brazil, Chile, Colombia, and Peru, while Mexico posts a large deficit.

Table 2. Export composition of Latin American countries (average 2005, 2010, 2016; millions of dollars and percentages). 


\begin{tabular}{|c|c|c|c|c|c|c|c|c|c|c|c|c|}
\hline & \multicolumn{2}{|c|}{ ARG } & \multicolumn{2}{|c|}{ BRA } & \multicolumn{2}{|c|}{ CHL } & \multicolumn{2}{|c|}{ COL } & \multicolumn{2}{|c|}{ MEX } & \multicolumn{2}{|c|}{ PER } \\
\hline & USD & $\%$ & USD & $\%$ & USD & $\%$ & USD & $\%$ & USD & $\%$ & USD & $\%$ \\
\hline Primary products & 25,938 & 46.8 & 52,865 & 31.4 & 27,878 & 48.1 & 17,388 & 56.7 & 42,436 & 14.4 & 8,624 & 29.0 \\
\hline Manufactures that process natural resources (broad concept) & 18,922 & 34.2 & 76,527 & 45.4 & 27,460 & 47.4 & 9,860 & 32.1 & 63,932 & 21.6 & 14,916 & 50.1 \\
\hline Based on natural resources (narrow concept) & 12,556 & 22.7 & 52,432 & 31.1 & 24,318 & 42.0 & 4,779 & 15.6 & 21,372 & 7.2 & 12,510 & 42.1 \\
\hline In agricultural resources & 8,515 & 15.4 & 24,749 & 14.7 & 7,623 & 13.2 & 1,439 & 4.7 & 10,745 & 3.6 & 1,137 & 3.8 \\
\hline In other resources & 4,041 & 7.3 & 27,683 & 16.4 & 16,696 & 28.8 & 3,340 & 10.9 & 10,627 & 3.6 & 11,373 & 38.2 \\
\hline Low-tech manufacturing & 2,313 & 4.2 & 11,804 & 7.0 & 1,435 & 2.5 & 2,315 & 7.5 & 30,228 & 10.2 & 1,902 & 6.4 \\
\hline Process-based medium-technology manufacturing & 4,053 & 7.3 & 12,291 & 7.3 & 1,707 & 2.9 & 2,766 & 9.0 & 12,333 & 4.2 & 503 & 1.7 \\
\hline Other (medium technology, high technology, and unclassified) & 10,528 & 19.0 & 39,168 & 23.2 & 2,593 & 4.5 & 3,438 & 11.2 & 189,103 & 64.0 & 6,205 & 20.9 \\
\hline Total & 55,387 & 100 & 168,560 & 100 & 57,932 & 100 & 30,685 & 100 & 295,471 & 100 & 29,744 & 100 \\
\hline
\end{tabular}

Source: Prepared by the authors based on data from UNCTAD (2020).

\section{lii. Results And Discussion}

The big exporters of these products are divided into two categories: 1) countries endowed with natural resources and which, to a greater or lesser extent, have developed a manufacturing industry that processes them; and 2) countries that lack the natural-resource base, which import them and have built up a large, sophisticated manufacturing export industry that processes them (Germany, Japan, and Korea).

Table 3 indicates the weight of the chains analyzed here in the total exports of goods from six Latin American countries (annual average for the years 2005, 2010, and 2016). The data refer to the total of each chain, without considering the level of processing of the products involved. Products in the petrochemical chain make up an important part of the exports of several Latin American countries. They contributed $10 \%$ of Brazil's exports; $11.1 \%$ of Mexico's; $8.9 \%$ of Argentina's; and $89.5 \%$ of Venezuela's. Copper is an important item in Chile and Peru's exports. Various types of copper exports represented $51 \%$ of Chile's exports and, in Peru, 22.4\%. In the iron-steel chain, the data for Brazil and Mexico contrast:

In Brazil, the weight of these exports increased to $16.2 \%$, while in Mexico they barely reached $2.3 \%$. However, we include the data for Mexico because the composition of exports by level of iron and steel processing in Mexico is considerably more complex than in Brazil. Finally, soybean chain products are a significant part of Brazil and Argentina's export baskets, accounting for $10 \%$ and $25.3 \%$, respectively.

Table 3. Weight of petrochemical (Brazil, Mexico, Argentina, and Venezuela), copper (Chile and Peru), iron and steel (Brazil and Mexico) and soybean (Brazil and Argentina) exports in total exports (average 2005, 2010, 2016; percentages). 


\begin{tabular}{|c|c|}
\hline Chains & $\%$ in exports of goods \\
\hline \multicolumn{2}{|c|}{ Petrochemicals $^{1} /$} \\
\hline BRA & 10.0 \\
\hline MEX & 11.1 \\
\hline ARG & 8.9 \\
\hline VEN & 89.5 \\
\hline \multicolumn{2}{|c|}{ Copper $^{2} /$} \\
\hline CHL & 51.0 \\
\hline PER & 22.4 \\
\hline \multicolumn{2}{|c|}{ Iron-steel $^{2}$ / } \\
\hline BRA & 16.2 \\
\hline MEX & 2.3 \\
\hline \multicolumn{2}{|c|}{ Soybeans ${ }^{3}$ / } \\
\hline BRA & 10.0 \\
\hline ARG & 25.3 \\
\hline
\end{tabular}

Source: Prepared by the authors based on data from Gaulier and Zignago (2010) and FAOSTAT.

Note: ${ }^{1 /}$ Includes raw materials, refined products, and basic, intermediate, and final petrochemicals. Data correspond to the average of 2007, 2010, and 2016. ${ }^{2 /}$ Excludes end-use products. ${ }^{3 /}$ Includes seed, oil, and cake.

\section{Petroleum and petroleum products}

The oil-transformation chain is complex. From crude oil, once refined, inputs are derived for the basic petrochemical industry, from whose products intermediate and final petrochemicals are obtained.

The largest exporters of oil and petroleum products in the region are Venezuela (USD 40.4 billion on average for the years considered), Mexico and Brazil (USD 35.5 billion and USD 17.9 billion, respectively). In Table 4 we have also included data from Argentina which, although it exports much less (USD 5.5 billion), has a composition of exports by product that is quite different than that of the rest of the countries in the region. While in Venezuela, Mexico, and Brazil, the largest share is made up of crude oil (78.1\% in Venezuela; $79.3 \%$ in Mexico and $64.4 \%$ in Brazil), in Argentina this proportion is substantially lower (28.6\%). In Argentina refined oil and petrochemicals account for 46.5 and $20.5 \%$ of total exports of oil, natural gas, and their derivatives. The opposite extreme occurs in Venezuela. Although its exports of refined oil are an important proportion of the total (19.6\%), petrochemical exports are marginal. In the petrochemical chain, Mexico has an export composition like that of Venezuela, but with less refined oil $(9.9 \%)$ and more petrochemicals (10.3\%). Brazil is in an intermediate situation between Argentina, on the one hand, and Venezuela and Mexico, on the other: Its refined oil and petrochemical exports account for $35.3 \%$ of the total.

Table 4. Exports from Brazil, Mexico, Argentina, and Venezuela by processing stage of the petrochemical chain (average 2007, 2010, 2016; millions of dollars and percentages). 


\begin{tabular}{|c|c|c|c|c|c|c|c|c|}
\hline \multirow[t]{2}{*}{ Stages } & \multicolumn{2}{|c|}{ BRA } & \multicolumn{2}{|c|}{ MEX } & \multicolumn{2}{|c|}{ ARG } & \multicolumn{2}{|c|}{ VEN } \\
\hline & USD & $\%$ & USD & $\%$ & USD & $\%$ & USD & $\%$ \\
\hline Raw materials & 11,535 & 64.6 & 27,473 & 79.7 & 1,806 & 33.0 & 31,553 & 78.1 \\
\hline Natural gas & 39 & 0.2 & 155 & 0.5 & 241 & 4.4 & 0 & 0.0 \\
\hline Crude oil & 11,496 & 64.4 & 27,318 & 79.3 & 1,565 & 28.6 & 31,552 & 78.1 \\
\hline Refined petroleum products & 2,187 & 12.2 & 3,425 & 9.9 & 2,545 & 46.5 & 7,933 & 19.6 \\
\hline Oils and preparations & 2,033 & 11.4 & 3,372 & 9.8 & 1,795 & 32.8 & 7,474 & 18.5 \\
\hline Liquefied petroleum gases & 31 & 0.2 & 50 & 0.1 & 672 & 12.3 & 94 & 0.2 \\
\hline Others $^{1 /}$ & 123 & 0.7 & 3 & 0.0 & 78 & 1.4 & 366 & 0.9 \\
\hline Basic petrochemicals & 740 & 4.1 & 116 & 0.3 & 115 & 2.1 & 510 & 1.3 \\
\hline Acyclic & 329 & 1.8 & 67 & 0.2 & 61 & 1.1 & 404 & 1.0 \\
\hline Cyclical & 393 & 2.2 & 26 & 0.1 & 39 & 0.7 & 14 & 0.0 \\
\hline Others & 18 & 0.1 & 23 & 0.1 & 15 & 0.3 & 92 & 0.2 \\
\hline Intermediate petrochemicals & 801 & 4.5 & 836 & 2.4 & 176 & 3.2 & 91 & 0.2 \\
\hline Polycarboxylic acids & 56 & 0.3 & 379 & 1.1 & 18 & 0.3 & 3 & 0.0 \\
\hline Cyclohexane, styrene, ethylbenzene, and cumene & 37 & 0.2 & 10 & 0.0 & 88 & 1.6 & 0 & 0.0 \\
\hline Acyclic ethers & 222 & 1.2 & 2 & 0.0 & 7 & 0.1 & 1 & 0.0 \\
\hline Others $^{1 /}$ & 485 & 2.7 & 446 & 1.3 & 64 & 1.2 & 86 & 0.2 \\
\hline Final petrochemicals & 2,592 & 14.5 & 2,606 & 7.6 & 834 & 15.2 & 316 & 0.8 \\
\hline Synthetic rubbers & 252 & 1.4 & 290 & 0.8 & 39 & 0.7 & 0 & 0.0 \\
\hline Polyacetals, polycarbonates, alkyd resins, polyethers, and polyesters & 251 & 1.4 & 663 & 1.9 & 78 & 1.4 & 5 & 0.0 \\
\hline Polymers of vinyl chloride or other halogenated olefins & 83 & 0.5 & 250 & 0.7 & 111 & 2.0 & 10 & 0.0 \\
\hline Styrene polymers & 66 & 0.4 & 496 & 1.4 & 18 & 0.3 & 4 & 0.0 \\
\hline Ethylene polymers & 1,438 & 8.1 & 262 & 0.8 & 396 & 7.2 & 17 & 0.0 \\
\hline Others $^{1 /}$ & 503 & 2.8 & 644 & 1.9 & 191 & 3.5 & 279 & 0.7 \\
\hline Total & 17,854 & 100 & 34,456 & 100 & 5,476 & 100 & 40,403 & 100 \\
\hline
\end{tabular}

Source: Prepared by the authors based on data from Gaulier and Zignago (2010).

Note: ${ }^{1 /}$ Includes product categories with a share of less than $1 \%$ in the total exports of the petrochemical chain of all countries at the same moment.

Table 5 shows the main destination markets for the exports of oil and its derivatives from the Latin American countries considered. For Mexico and Venezuela, the most important market is the United States. The markets of Argentina and Brazil are considerably more diversified (United States, Chile and China). The United States and China are buyers of raw materials. Oil makes up more than $80 \%$ of what Mexico and Venezuela sell to it and $72.2 \%$ of what Brazil sells. Like the United States, China basically purchases raw materials.

Other major exporters of oil, natural gas, and their refined and petrochemical derivatives are Saudi Arabia (USD 207 billion); Russia (USD 194.8 billion), and the United States (USD 116.6 billion). Saudi Arabia basically exports crude oil; Russia exports crude and refined oil; and the United States divides exports between refined oil and petrochemicals. In a second category are the Netherlands (90.6 billion), Norway ( 69.4 billion), and the United Kingdom (52.9 billion), countries where raw materials account for more than $20 \%$ of the chain's exports. But while Norway exports mainly raw materials $(86.1 \%$ of its exports), the Netherlands and the United Kingdom also have strong refining and petrochemical industries. Other countries do not have raw materials, i.e., they import them, process them, and export oil derivatives in significant quantities (Germany, Korea, China, and Japan: 63.4,59.7, 38.1, and USD 35.9 billion, respectively). 
Table 5. Main markets for petrochemical chain exports from Brazil, Mexico, Argentina, and Venezuela (average 2007, 2010, 2016; percentages).

\begin{tabular}{|c|c|c|c|c|c|}
\hline & Importers & Total $^{1 /}$ & Raw materials & Refined products & Final petrochemicals \\
\hline \multirow[t]{6}{*}{ BRA } & USA & 25.1 & 28.1 & 23.4 & 9.7 \\
\hline & $\mathrm{CHN}$ & 18.1 & 25.7 & 0.1 & 7.2 \\
\hline & $\mathrm{CHL}$ & 8.4 & 11.2 & 0.2 & 6.0 \\
\hline & Subtotal (3 countries) & 51.6 & 65.0 & 23.7 & 22.9 \\
\hline & Rest of the World & 48.4 & 35.0 & 76.3 & 77.1 \\
\hline & Total & 100 & 100 & 100 & 100 \\
\hline \multirow[t]{6}{*}{ MEX } & USA & 75.2 & 79.5 & 78.8 & 43.1 \\
\hline & $\mathrm{CHN}$ & 1.5 & 1.0 & 1.1 & 3.5 \\
\hline & ESP & 7.5 & 9.0 & 0.1 & 2.2 \\
\hline & Subtotal (3 countries) & 84.2 & 89.6 & 80 & 48.8 \\
\hline & Rest of the World & 15.8 & 10.4 & 20 & 51.2 \\
\hline & Total & 100 & 100 & 100 & 100 \\
\hline \multirow[t]{6}{*}{ ARG } & USA & 21.2 & 33.5 & 18.0 & 1.7 \\
\hline & $\mathrm{CHN}$ & 9.4 & 27.2 & 0.2 & 1.1 \\
\hline & CHL & 19.2 & 30.4 & 14.5 & 11.4 \\
\hline & Subtotal (3 countries) & 49.7 & 91.1 & 32.6 & 14.3 \\
\hline & Rest of the World & 50.3 & 8.9 & 67.4 & 85.7 \\
\hline & Total & 100 & 100 & 100 & 100 \\
\hline \multirow[t]{6}{*}{ VEN } & USA & 62.2 & 68.9 & 38 & 25.9 \\
\hline & $\mathrm{CHN}$ & 9.7 & 8.8 & 14.5 & 0.4 \\
\hline & IND & 7.3 & 9.3 & 0.0 & 0.3 \\
\hline & Subtotal (3 countries) & 79.1 & 86.9 & 52.5 & 26.7 \\
\hline & Rest of the World & 20.9 & 13.1 & 47.5 & 73.3 \\
\hline & Total & 100 & 100 & 100 & 100 \\
\hline
\end{tabular}

Source: Prepared by the authors based on data from Gaulier and Zignago (2010).

Note: ${ }^{1 /}$ Includes raw materials, refined products, and basic, intermediate, and final petrochemicals.

Figure 1 shows four data points from the trade of oil and its derivatives of 15 countries. First, the value of their exports, indicated by the size of the circle (circles are shown at the bottom of the figure to give an image of the amount exported by the countries). Second, the abscissa axis shows the position of their exports in the value chain. This axis distinguishes five phases of the petroleum value chain and its transformation: 1. Raw materials; 2. Refined petroleum products; 3 Basic petrochemicals; 4 . Intermediate petrochemicals; and 5 . Final petrochemicals. The location of the countries along this axis shows their position in the value chain according to the weight that exports of products from each stage have in each country's total exports of petroleum and petroleum products. Third, the ordinate axis indicates the average unit price (in dollars per kilogram) of exports of these products for each country. Price data was obtained by weighting the price of each of the products exported by each country by the share of each product in every country's total exports of oil and its derivatives. Rounding out, the signs next to the countries indicate whether total trade in petroleum products is posting a surplus (+) or a deficit (-) for the country in question.

Our sample of countries can be grouped into three categories: five are in the lower left part of the figure (Norway, Venezuela, Russia, Saudi Arabia, and Mexico), whose exports are dominated by crude oil and lightly processed refined products with a low unit price (from 0.40 USD for Norway and Mexico to 0.46 USD per kilo for Saudi Arabia). All these countries have oil trade surpluses. The second group is in 
the upper right-hand side of the figure (Japan and Germany), which are in deficit in oil and oil products trade, importing low-processed oil products and exporting secondary and final petrochemicals with high unit prices (1.01 and 1.30 USD per kilogram in Germany and Japan, respectively). The third group is made up of a scattered group of eight countries, heterogeneous both in terms of their location along the abscissa and ordinate axes. Note that due to the composition of exports, they are between stages 2 and 3 (Brazil, Great Britain, Argentina, India, and Holland), with unit prices between 0.46 (Brazil) and 0.73 (Holland), and stages 3 and 4 (United States, Korea, and China), with unit prices ranging from 0.47 dollars in the United States to 0.84 in Korea. All these countries are in deficit in the oil and petroleum-products trade.

\section{Copper}

Copper can be sold as concentrate, which contains approximately $30 \%$ of the metal. When smelted, blister copper is obtained with $96 \%$ copper, which, once refined, become copper anodes with a purity of $99.4 \%$ - 99.6\%; these then go through another refining process to obtain copper cathodes with $99.99 \%$ purity. The refined copper is used to produce semi-fabricated and end-use copper products.

Table 6 shows the composition of copper exports from Chile and Peru according to their degree of processing. The main conclusions that can be drawn from these data are the following: First, most of their exports are ores and concentrates and refined copper. The sum of these varieties totals more than $90 \%$ of copper exports in the two countries. Of the total exported by Chile, $38 \%$ is copper concentrate and $54 \%$ is refined copper. The respective percentages for Peru are $70 \%$ and $24.4 \%$. Second, the weight of exports of copper plus primary copper is substantially higher in Peru's exports than in Chile's. Further, the weight of exports of refined copper products is marginal in the two countries.

Table 6. Exports from Chile and Peru by copper processing stage (average 2005, 2010, and 2016; millions of dollars and percentages).

\begin{tabular}{lcccc}
\hline Stages & \multicolumn{2}{c}{ CHL } & \multicolumn{3}{c}{ PER } \\
& USD & $\%$ & USD & $\%$ \\
\hline Ores and concentrates & 11,076 & 38.0 & 5,464 & 70.0 \\
\hline Mattes, blister, and anodes & 1,853 & 6.4 & 131 & 1.7 \\
\hline Refined copper & 15,753 & 54.0 & $\mathbf{1 , 9 0 5}$ & $\mathbf{2 4 . 4}$ \\
\hline Cathodes and other forms of refined copper & 15,738 & 54.0 & 1,901 & 24.3 \\
\hline Copper bars, billets, and alloys & 14 & 0.0 & 4 & 0.1 \\
\hline Semi-finished products & $\mathbf{4 2 7}$ & $\mathbf{1 . 5}$ & $\mathbf{2 8 8}$ & $\mathbf{4 . 0}$ \\
\hline Rolled copper wire & 331 & 1.1 & 197 & 2.5 \\
\hline Other semi-fabricated products & 427 & 1.5 & 288 & 3.7 \\
\hline End-use products & $\mathbf{5 2}$ & $\mathbf{0 . 2}$ & $\mathbf{2 1}$ & $\mathbf{0 . 3}$ \\
\hline Total & $\mathbf{2 9 , 1 6 1}$ & $\mathbf{1 0 0}$ & $\mathbf{7 , 8 0 9}$ & $\mathbf{1 0 0}$ \\
\hline
\end{tabular}

Source: Prepared by the authors based on data from Gaulier and Zignago (2010).

Table 7 shows the main markets for Chilean and Peruvian exports of copper concentrate and refined copper. In both countries, more than $70 \%$ of exports goes to seven countries. China is the main export destination market (36\% for Chile and $41 \%$ for Peru). The rapid increase in China's weight as a destination market for Chilean and Peruvian exports is

noteworthy. In Chile, in 2005, 20\% of its copper exports went to China; by 2010 this percentage rose to $35.8 \%$, and to $47.3 \%$ in 2016 (Gaulier and Zignano 2010). In the case of Peru, the respective proportions are $19.2 \%, 26.2 \%$, and $61.2 \%$. Second place goes to Japan (12\% and $10 \%$, respectively). For Chile, other 
important markets are Korea, the United States, and Brazil. For Peru, they are the United States, Germany, and Brazil.

Chile is an exporter of concentrated and refined copper to China (37\% and $57.5 \%$ of total exports to China). In Peru's exports to China, primary copper is much more important: $83.2 \%$ is concentrate and $15.8 \%$ is refined copper. Japan's imports are more than $90 \%$ copper concentrate. In the case of Peru, its exports to Germany and Korea are also dominated by concentrate. In contrast, in Chile's exports to Germany, Korea, Brazil, and, particularly, the United States, refined copper accounts for between $43.9 \%$ and $96.8 \%$ of total copper exports.

Table 7. Main markets for copper exports from Chile and Peru (average 2005, 2010, and 2016; percentages).

\begin{tabular}{lcccccc}
\hline Countries & & \multicolumn{2}{c}{ CHL } & & \multicolumn{2}{c}{ PER } \\
& Total $^{1 / /}$ & Ores and concentrates & Refined copper & Total $^{1 /}$ & Ores and concentrates & Refined copper \\
\hline CHN & 35.9 & 34.4 & 37.6 & 41.0 & 46.8 & 25.5 \\
\hline JPN & 11.6 & 28.5 & 1.1 & 10.1 & 13.0 & 2.3 \\
\hline KOR & 8.2 & 6.8 & 8.8 & 3.9 & 5.3 & 0.2 \\
\hline USA & 6.6 & 0.0 & 11.6 & 6.3 & 0.0 & 24.6 \\
\hline BRA & 5.2 & 5.2 & 5.6 & 4.6 & 2.1 & 12.1 \\
\hline IND & 3.8 & 9.7 & 0.0 & 2.7 & 3.7 & 0.0 \\
\hline GER & 2.4 & 3.2 & 1.9 & 6.1 & 7.2 & 2.2 \\
\hline Subtotal (7 countries) & $\mathbf{7 3 . 6}$ & $\mathbf{8 7 . 8}$ & $\mathbf{6 6 . 7}$ & $\mathbf{7 4 . 7}$ & $\mathbf{7 8 . 0}$ & $\mathbf{6 6 . 9}$ \\
\hline Rest of the World & 26.4 & 12.2 & 33.3 & 25.3 & 22.0 & 33.1 \\
\hline Total & 100 & 100 & 100 & 100 & 100 & 100 \\
\hline
\end{tabular}

Source: Prepared by the authors based on data from Gaulier and Zignago (2010).

Note: ${ }^{1 /}$ Includesores and concentrates, matte, blister and anodes, and refined copper.

Copper importing countries are simultaneously exporters of copper products. They are importers of concentrate and refined copper, while their exports are dominated by semi-fabricated and final copper products. Among the major importers, the largest exporter of copper products is China, $85.1 \%$ of which are final products. The second place by exports goes to Germany, which divides them in similar proportions between semi-fabricated and final products. Third place goes to the United States, $63.5 \%$ of whose exports are made up of final products and $23.5 \%$ of semi-fabricated products. Japan and Korea are next and their exports are of final products ( $40.8 \%$ and $46.6 \%$, respectively); semi-fabricated products (28.4\% and $37.6 \%)$; and refined copper (30.6\% and $15.3 \%$ ). Although all these countries have a deficit balance in the total trade of copper products, the specialization in the processing of these products means that trade in final products is in surplus in China, which is also the case in Germany, Japan, and Korea with the exchange of semi-fabricated copper products.

As we have seen, in Chile and Peru the weight of exports of semi-fabricated and end-use products is marginal. This is not the case in Brazil where the combined contribution of these products amounts to $36 \%$ of total copper exports, with an average price of semi-fabricated copper alloys of USD 9.2/kilogram (vs. USD 4.6 for the same product exported by Chile and USD 5.3 for those exported by Peru).

Figure 2 is constructed using the same criteria as in Figure 1. The abscissa axis distinguishes five types of exported copper according to phases in its production process: 1. Ores and concentrates; 2. 
Blister copper; 3. Refined copper; 4. Semi-fabricated products; and 5. Final products. Peru and Chile are on the lower left, that is, their exports are concentrated between phases one and two with a weighted average unit price of USD 1.7 and USD 3.2 per kilogram. Japan, Germany, United States, China, and Korea are found at the top right, all deficit traders in copper, importers of low-processed copper and exporters of semi-processed and processed copper products, which have a significantly higher price. Japan's unit price of processed copper products is the highest (USD 9.3 per kilogram), followed by Germany's (USD 8.3).

For Chile, the unit price of concentrate is USD 1.9 per kilogram; refined copper, USD 5.5; and semifabricated products, USD 5.6. There is a notable dispersion in the unit price depending on the exporting country. The price differentials for the same products exported by different countries indicate that they are products with different qualities. Thus, the price of semi-fabricated products exported by Japan is USD 9.5 per kilogram, $70 \%$ higher than the price of these products exported by Chile and $46 \%$ higher than the same product exported by Germany. Depending on the specific product, prices can be very different from one another.

\section{Iron and steel}

Iron, from the extraction of the ore to its transformation into steel that is incorporated into other products, goes through five phases. The first is the extraction of the ore and its first processing, from which 60percent iron content concentrate is obtained. Next is the iron processing stage, from which pig iron is generated ( $94 \%$ concentration), and then the steelmaking and smelting stage (more than $98 \%$ concentration). Subsequently, the steel and cast iron are transformed into rolled products, such as coils, pipes, and tubes. These products are then used to manufacture finished steel products and end-use goods (Wang, Müller and Graedel, 2007).

Total exports of Brazil's iron-steel chain far exceed those of Mexico, totaling, on average for 2005, 2010, and $2016,16 \%$ of Brazilian exports vs. $2 \%$ of Mexico's (see Table 4). In the analysis that follows, data from Mexico are included since its exports are markedly more elaborate than Brazil's. Sixty-three percent of Brazil's exports correspond to ores and concentrates, while Mexico's exports are mostly distributed among rolled products (27\%); finished products (31\%); and end-use products (27\%). (See Table 8 ).

Table 8. Exports from Brazil and Mexico by iron-steel processing stage (average 2005, 2010, and 2016; millions of dollars and percentages).

Source: Prepared by the authors based on data from Gaulier and Zignago (2010).

Table 9 displays the main destination markets for exports of the Brazilian and Mexican iron and steel chain. The main market for Brazilian exports is China (32\% of the total), followed by the United States, and Japan. Exports of ores and concentrates, which account for almost $60 \%$ of Brazil's exports, $45 \%$ go to China. Although China is not an important market for Mexico, it is an important market for exports of ores and concentrates ( $56 \%$ of the total). For Mexico, the most important foreign market for steel products is the United States (75\% of the total), most of which is made up of rolled, finished, and end-use products $(88.6 \%)$. 


\begin{tabular}{lcccc}
\hline Stages & BRA & \multicolumn{2}{c}{ MEX } \\
& USD & $\%$ & USD & $\%$ \\
\hline Ores and concentrates & 18,011 & $\mathbf{6 2 . 6}$ & 133 & 1.5 \\
\hline Pig iron and alloys & $\mathbf{2 , 9 0 5}$ & 10.1 & $\mathbf{8 6}$ & 1.0 \\
\hline Pig iron & 1,215 & 4.2 & 0 & 0.0 \\
\hline Alloys & 1,668 & 5.8 & 85 & 1.0 \\
\hline Pig iron (sponge) & 21 & 0.1 & 0 & 0.0 \\
\hline Steel and cast iron & $\mathbf{2 , 7 0 9}$ & $\mathbf{9 . 4}$ & $\mathbf{1 , 1 1 2}$ & 12.5 \\
\hline Ingots & 41 & 0.1 & 25 & 0.3 \\
\hline Other foundry products & 76 & 0.3 & 196 & 2.2 \\
\hline Blooms, billets, and slabs & 2,593 & 9.0 & 890 & 10.0 \\
\hline Rolled steel products & $\mathbf{3 , 5 2 2}$ & 12.2 & 2,430 & 27.3 \\
\hline Coils & 668 & 2.3 & 258 & 2.9 \\
\hline Plates & 1,383 & 4.8 & 792 & 8.9 \\
\hline Wire and rods & 981 & 3.4 & 510 & 5.7 \\
\hline Angles & 113 & 0.4 & 154 & 1.7 \\
\hline Tubes and pipes & 377 & 1.3 & 716 & 8.1 \\
\hline Finished steel products & $\mathbf{1 , 0 5 1}$ & $\mathbf{3 . 7}$ & $\mathbf{2 , 7 3 9}$ & $\mathbf{3 0 . 8}$ \\
\hline Structures & 117 & 0.4 & 463 & 5.2 \\
\hline Other finished products & 763 & 2.6 & 2,014 & 22.7 \\
\hline Wires, cables, and ropes & 73 & 0.3 & 169 & 1.9 \\
\hline Bolts and screws & 99 & 0.3 & 92 & 1.0 \\
\hline End-use products & $\mathbf{5 8 8}$ & $\mathbf{2 . 0}$ & $\mathbf{2 , 3 9 1}$ & $\mathbf{2 6 . 9}$ \\
\hline Sanitary, plumbing, or heating accessories & 17 & 0.1 & 183 & 2.1 \\
\hline Tools & 229 & 0.8 & 257 & 2.9 \\
\hline Cutlery & 233 & 0.8 & 371 & 4.2 \\
\hline Other fabricated metal products & 109 & 0.4 & 1,575 & 17.7 \\
\hline Office supplies and stationery & 1 & 0.0 & 4 & 0.0 \\
\hline Total & 100 & $\mathbf{8 , 8 9 0}$ & 100 \\
\hline
\end{tabular}

Table 9. Main markets for iron-steel exports from Brazil and Mexico (average 2005, 2010, and 2016; percentages).

\begin{tabular}{|c|c|c|c|c|c|c|}
\hline \multirow[t]{11}{*}{ BRA } & Importers & Total $^{1 /}$ & $\begin{array}{c}\text { Ores and } \\
\text { concentrates }\end{array}$ & $\begin{array}{l}\text { Pig iron } \\
\text { and alloys }\end{array}$ & $\begin{array}{c}\text { Steel } \\
\text { and cast } \\
\text { iron } \\
\end{array}$ & $\begin{array}{c}\text { Laminated } \\
\text { products }\end{array}$ \\
\hline & $\mathrm{CHN}$ & 31.6 & 44.7 & 11.6 & 2.4 & 3.8 \\
\hline & USA & 8.6 & 0.8 & 31.4 & 28.8 & 14.4 \\
\hline & JPN & 8.1 & 10.7 & 8.7 & 0.0 & 0.1 \\
\hline & GER & 5.0 & 6.1 & 2.6 & 4.4 & 1.8 \\
\hline & KOR & 4.6 & 4.2 & 2.4 & 13.9 & 1.6 \\
\hline & ITA & 2.9 & 3.3 & 1.9 & 1.2 & 3.4 \\
\hline & NLD & 2.9 & 2.7 & 8.5 & 0.9 & 1.1 \\
\hline & $\begin{array}{l}\text { Subtotal (7 } \\
\text { countries) }\end{array}$ & 63.8 & 72.4 & 67.2 & 51.5 & 26.1 \\
\hline & $\begin{array}{l}\text { Rest of the } \\
\text { World }\end{array}$ & 36.2 & 27.6 & 32.8 & 48.5 & 73.9 \\
\hline & Total & 100 & 100 & 100 & 100 & 100 \\
\hline \multirow[t]{4}{*}{ MEX } & Importers & Total $^{2 /}$ & $\begin{array}{l}\text { Steel and } \\
\text { cast iron }\end{array}$ & $\begin{array}{c}\text { Laminated } \\
\text { products }\end{array}$ & $\begin{array}{l}\text { Finished } \\
\text { products }\end{array}$ & $\begin{array}{l}\text { End-use } \\
\text { products }\end{array}$ \\
\hline & USA & 74.5 & 66.5 & 67.4 & 81.7 & 77.2 \\
\hline & $\begin{array}{l}\text { Rest of the } \\
\text { World }\end{array}$ & 25.5 & 33.5 & 32.6 & 18.3 & 22.8 \\
\hline & Total & 100 & 100 & 100 & 100 & 100 \\
\hline
\end{tabular}

Source: Prepared by the authors based on data from Gaulier and Zignago (2010).

Note: ${ }^{1 /}$ Thetotal for Brazil includes the first four stages of the ironsteel chain. ${ }^{2 /}$ Thetotal for Mexico includes the last four stages of the chain.

Exports of iron and steel products from Brazil and eight other major exporters (China, Germany, Japan, the United States, Australia, Italy, Korea, and the Netherlands) amount to USD 367 billion (annual average 2005,2010 , and 2016), most of which is made up of rolled products ( $40 \%$ of the total), followed by finished products, end-use products and concentrates (25\%, $15 \%$, and $13 \%$ of the total, respectively). The major exporters of concentrates are Australia and Brazil (accounting for $98 \%$ of the total) and the major importer is China (70\% of the total imported by these countries). With respect to rolled products, the largest exporters are China, Japan, Germany, and Korea (22\%, 20\%, $18 \%$, and $13 \%$ of total rolled products exported by these countries). In finished steel products and end-use products, the countries with the greatest weight in exports are China and Germany (in finished products, $37 \%$ and $20 \%$, and in end-use products, $35 \%$ and $26 \%$ of the total of these products exported by the nine countries, respectively).

The nine countries, except for the United States and the Netherlands, have trade surpluses in the exchange of steel products. The case of China stands out, whose surplus is the result of the large trade surplus in rolled products and finished and end-use iron and steel products, which more than offsets the trade deficit in concentrates. The same can be said of Germany, Japan, Korea, and Italy. In Australia, the opposite situation occurs: It is the surplus in the trade of concentrates that exceeds the deficit in the exchange of more processed products. The Brazilian steel industry shows a higher degree of maturity than the Australian one. Although most of its surplus comes from trade in concentrates, it also has a 
surplus in pig iron and alloys, steel and cast iron, and rolled steel. Mexico's trade is in deficit in all products, except for steel and cast iron. The U.S. trade deficit is the largest of the countries considered and is in deficit in all products, except for trade in concentrates.

Figure 3 depicts the information for the iron and steel chain presented in the same terms as Figure 1. Here, six phases in the production chain can be distinguished: 1 . Ores and concentrates, 2. Pig iron and alloys, 3. Steel and cast Iron, 4. Rolled steel products, 5. Finished steel products, and 6. End-use steel products. Australia and Brazil are in the lower left zone of the figure, that is, they are exporters of primary iron with low unit prices (USD 0.07 and 0.09 per kilogram, respectively). At the upper right end are the countries exporting high-priced steel products, led by Germany and Italy, whose exports have a price of USD 1.85 and 1.67 per kilogram. Some of these countries have surpluses in the iron and steel trade, although they do not have rich deposits of the mineral, so they are importers of primary iron and exporters of steel processed to a greater extent than the steel they import. Note that China is in this group of countries, which shows that it is vigorously developing its refined-products steel industry. Mexico's position in the export chain is very different from that of Brazil. Although it is a relatively small exporter, it exports products with an average unit price of USD 1.11 per kilogram, 12 times the price of the product exported by Brazil.

More detailed data confirm what we have already highlighted in the case of copper, i.e., for the same product, unit prices can differ considerably depending on the exporting country. This indicates that the market for these products has a clear segmentation by quality.

\section{Soybeans}

The value chain of soybean production and its derivatives is short. Once harvested, soybeans are ground to obtain two products: oil, which is used in the food industry, and soybean cake, which is used to produce fodder, an essential product for the livestock industry.

The largest soybean producers are the United States, Brazil, and Argentina, while the largest importer is China. Table 10 shows that, together, the three countries contribute $80.4 \%$ of world soybean exports (United States, 30.8\%; Brazil, 27.2\%; Argentina, 22.5\%). Argentine exports are of more processed products than those of Brazil and the United States. Argentina accounts for $44 \%$ of world soybean oil exports and $37 \%$ of soybean cake exports, while Brazil and the United States concentrate on soybeans (45\% and $33 \%$, respectively, of world soybean exports).

Table 10. Main countries of origin of world soybean exports (average 2005, 2010, and 2016; millions of dollars and percentages). 


\begin{tabular}{|c|c|c|c|c|c|c|c|c|}
\hline \multirow[t]{2}{*}{ Countries } & \multicolumn{2}{|c|}{ Total } & \multicolumn{2}{|c|}{ Soybeans (seed) } & \multicolumn{2}{|c|}{ Soybean oil } & \multicolumn{2}{|c|}{ Soybean cake } \\
\hline & USD & $\%$ & USD & $\%$ & USD & $\%$ & USD & $\%$ \\
\hline USA & 19,620 & 30.8 & 16,213 & 44.7 & 896 & 11.3 & 2,510 & 12.8 \\
\hline BRA & 17,336 & 27.2 & 11,906 & 32.9 & 1,171 & 14.7 & 4,259 & 21.8 \\
\hline ARG & 14,322 & 22.5 & 3,505 & 9.7 & 3,496 & 44.0 & 7,321 & 37.4 \\
\hline Subtotal & 51,279 & 80.4 & 31,625 & 87.3 & 5,563 & 70 & 14,091 & 72.1 \\
\hline Rest of the World & 12,464 & 19.6 & 4,615 & 12.7 & 2,389 & 30 & 5,460 & 27.9 \\
\hline Total & 63,742 & 100 & 36,240 & 100 & 7952 & 100 & 19,550 & 100 \\
\hline
\end{tabular}

Source: Prepared by the authors based on data from FAO (2020).

China is the main market for the three countries' soybean exports. Argentina sells $22 \%$ of its total exports to China, Brazil $47 \%$, and the United States $49 \%$. China's dominance as an importer is overwhelming in terms of the soybean exports of the three countries (Argentina, 82\%; Brazil, 65\%; and the United States, $58 \%)$. But in exports of processed soybean products, China's importance is considerably less. Soybean oil constitutes $24 \%$ of Argentina's processed soybean exports, of which only $9 \%$ goes to China and soybean cake (51\% of exports) is not sold in China. In other words, Argentina's oil and cake exports are more diversified by destination markets than those of seeds. The main market for oil exported by this country is India (35\% of the total) and the rest is distributed among many countries. The market for Argentina's soybean cake is even more diversified. Less markedly, the same situation is true for exports from Brazil and the United States. In both countries, China is the main market for seed exports $(65 \%$ for Brazil and $58 \%$ for the United States), but in terms of oil, China absorbs $32 \%$ of Brazil's exports and $19 \%$ of those of the United States, while both countries do not export soybean cake to China (see Table 11).

Table 11. Main markets for soybean exports from Argentina, Brazil, and the United States (average 2005, 2010, and 2016; percentages).

\begin{tabular}{|c|c|c|c|c|c|}
\hline \multirow[t]{9}{*}{ ARG } & Importers & Total & Soybeans (seed) & Soybean oil & Soybean cake \\
\hline & $\mathrm{CHN}$ & 22.4 & 82.1 & 9.0 & 0.2 \\
\hline & IND & 9.1 & 0.0 & 35.2 & 1.0 \\
\hline & ESP & 4.2 & 0.0 & 1.0 & 7.8 \\
\hline & NLD & 4.0 & 0.0 & 0.2 & 7.8 \\
\hline & IRN & 3.3 & 1.1 & 5.0 & 3.5 \\
\hline & Subtotal (5 countries) & 43.0 & 83.2 & 50.4 & 20.3 \\
\hline & Rest of the World & 57.0 & 16.8 & 49.6 & 79.7 \\
\hline & Total & 100 & 100 & 100 & 100 \\
\hline \multirow[t]{8}{*}{ BRA } & $\mathrm{CHN}$ & 46.9 & 65.1 & 32.1 & 0.0 \\
\hline & NLD & 10.4 & 6.5 & 2.0 & 23.4 \\
\hline & THA & 4.6 & 3.3 & 0.1 & 9.5 \\
\hline & ESP & 4.4 & 5.1 & 0.8 & 3.2 \\
\hline & FRA & 4.3 & 0.6 & 0.7 & 15.8 \\
\hline & Subtotal (5 countries) & 70.6 & 80.6 & 35.7 & 51.9 \\
\hline & Rest of the World & 29.4 & 19.4 & 64.3 & 48.1 \\
\hline & Total & 100 & 100 & 100 & 100 \\
\hline \multirow[t]{3}{*}{ USA } & $\mathrm{CHN}$ & 48.6 & 57.8 & 18.6 & 0.0 \\
\hline & Rest of the World & 51.4 & 42.2 & 81.4 & 100.0 \\
\hline & Total & 100 & 100 & 100 & 100 \\
\hline
\end{tabular}

Source: Prepared by the authors based on data from FAO (2020).

Figure 4 shows the export profile of the three major producers of soybeans and their derivatives. In the graph, phase 1 corresponds to the seed; phase 2 to the production of soybean cake, and phase 3 to 
soybean oil. We have placed the oil in phase 3 because it is the most processed product, although this does not mean that this product is derived from soybean cake. The figure displays the unit price of soybean exports by type of product exported by the three countries. The seed is exported by the three countries at average prices of between USD 0.32 (Argentina) and USD 0.39 (United States) per kilogram, while the average price of oil is between USD 1.18 (United States) and USD 1.57 (Brazil). The price of soybean cake is lower because it is the residual product of the grinding stage. The United States has higher prices than Argentina and Brazil for soybean seed and soybean cake, suggesting that US exports of these products are of better quality.

\section{Iv. Conclusions}

(1) Natural resources are not always a curse. There are high-income countries where exports of primary products and the manufactures that transform them are a substantial part of their exports.

(2) In many highly developed countries that are not particularly rich in natural resources, there is a powerful industry for exporting manufactured products that process natural resources that are imported and to which value is added in these economies.

(3) Latin American countries are characterized by a concentration of exports of primary products and manufactures based on them with a low level of transformation.

(4) One of the relevant lines of industrial policy for Latin American countries is to promote the domestic processing of natural resources with a view to exporting higher value products and, therefore, with a higher domestic income content.

(5) In recent years, China has developed into the most important market for the natural resources exported by Latin American countries, becoming at the same time a major world exporter of manufactures based on the transformation of these resources. Latin America needs to avoid being forced, for the second time in history, to become a supplier of raw materials for other countries.

(6) Any industrial policy implemented by Latin American countries that references the above conclusions will face formidable obstacles requiring very strong companies with an export vocation, whether they be private, public, or mixed.

\section{Declarations}

\section{Ethics approval and consent to participate}

Not applicable

\section{Consent for publication}

Not applicable 
Availability of data and materials

The details about the datasets and methods used in this research can be found in the Online Appendix A.1. (Supplementary Material).

\section{Competing interests}

No applicable

\section{Funding}

National Council of Science and Technology of Mexico (CONACyT) through project A1-S-47786.

\section{Authors' contributions}

Gerardo Fujii-Gambero: Definition of the subject and the strategy of research and writing of the paper.

Rodrigo Morales-López: Search for databases and bibliography, statistical processing, tables and figures and revision of drafts and final version.

\section{Acknowledgements}

Not applicable

\section{Authors' information (optional)}

Gerardo Fujii-Gambero has a Ph.D. in Economics and is a Professor in the College of Economics of the National Autonomous University of Mexico.

Selection of last publications:

Rosa Gómez Tovar, Gerardo Fujii-Gambero y Michel Betancourt-Gómez (2021), “Importance, level of insertion, and position of Korea's and Mexico's exporting sectors into the world's exports network, Economía UNAM, vol. 18, № 53 (Spanish).

Gerardo Fujii-Gambero, Manuel García-Ramos y Rosa Gómez Tovar (2021),“Evolution of the global trade network in terms of added value", Problemas del Desarrollo, Vol. 52, Número especial en honor de Jaime Ros (Spanish).

Gerardo Fujii-Gambero, Rosa Gómez Tovar y Manuel García-Ramos (2020), "A typology of the insertion of countries in global export trade networks in value added, El Trimestre Económico, Vol. LXXXVII (3), № 347, julio-septiembre (Spanish).

Gerardo Fujii-Gambero, Manuel García-Ramos and Julio López Gallardo (2020), "Trade and growth in middle-income economies: Mexico, Korea, and China", in Economic Growth and Macroeconomic 
Stabilization Policies in Post - Keynesian Economics, edited by H. Bougrine and L-P. Rochon, UK and USA: Edward Elgar.

Manuel García-Ramos y Gerardo Fujii-Gambero (2018), "A linkage analysis of the global value network", The International Trade Journal.

Gerardo Fujii-Gambero and Rosario-Cervantes-Martínez (2017), “The weak linkages between processing exports and the internal economy. The Mexican case", Economic Systems Research, Vol. 29, № 4, December.

Gerardo Fujii G., Rosario Cervantes M. and Ana Sofía Fabián R, (2016), "The labour content of Mexican manufactures, 2008 and 2012", CEPAL Review, N 119, August.

Gerardo Fujii-Gambero and Manuel García-Ramos (2015), "Revisiting the quality of exports”, Journal of Economic Structures

Rodrigo Morales-López has a Ph.D. in Economics and is a Postdoctoral Researcher in the College of Economics of the National Autonomous University of Mexico.

Selection of last publications:

Moreno-Brid, J.C. y Morales-López, R. (2020): “Central America and the pandemic: macroeconomic policy challenges", CEPAL Review, nº 132.

Morales-López, R. (2020): “Centroamérica ante la crisis del coronavirus: Una mirada desde la economía”, Economía UNAM, vol. 17, $\mathrm{n}^{\circ}$ 51. (Spanish)

Morales-López, R. (2019): “Cadenas de valor y la exportación de manufacturas mexicanas a Estados Unidos", Comercio Exterior, n 19. (Spanish)

Morales-López, R. (2019): “Impacto de la demanda interna de terceros países en la balanza comercial de la manufactura guatemalteca: El caso de las relaciones comerciales con Estados Unidos, México y El Salvador", Banca Central, nº 78. (Spanish)

Morales-López, R. y Galdámez, C. (2019): “Contribución y caracterización de las ramas productivas al proceso de integración económica de Centroamérica, 2005-2016”, El Trimestre Económico, vol. 86, nº 344. (Spanish)

Vázquez, R. y Morales-López, R. (2018): "Trade integration and export diversification: El Salvador's trade with the United States and Central America", CEPAL Review, ${ }^{\circ} 126$.

Vázquez, R. y Morales-López, R. (2017): “Diversificación de las exportaciones y competitividad externa en la industria. Hacia la construcción de una tipología para el caso de países de ingresos medios", Cuadernos de Economía (Spain), vol. 40, nº 114. (Spanish) 


\section{References}

1. Altman, M. (2003). Staple-theory and export-led growth: Constructing differential growth. Australian Economic History Review, 43(3), 230-255.

2. Auty, R. M. (2001). The Political Economy of Resource-Driven Growth. European Economic Review, 45(4-6), 839-846.

3. Berend, I. T., \& Ránki, G. (1982). The European Periphery and Industrialization 1780-1914. Cambridge and Budapest: Cambridge University Press and Akadémiai Kiadó.

4. Blomström, M., \& Kokko, A. (2007). From Natural Resources to High-Tech Production: The Evolution of Industrial Competitiveness in Sweden and Finland. In D. Lederman \& W. F. Maloney (Eds.), Natural Resources. Neither Curse nor Destiny. Washington, DC: The World Bank.

5. Blomström, M., \& Meller, P. (1991). Issues for Development: Lessons from Scandinavian-Latin American Comparisons. In M. Blomström \& P. Meller (Eds.), Diverging Paths: Comparing a Century of Scandinavian and Latin American Economic Development. Washington, DC: Inter-American Development Bank.

6. Food and Agriculture Organization (FAO). (2020). FAOSTAT. Detailed Trade Matrix. Retrieved from http://www.fao.org/faostat/en/\#data/TM. Retrieved September 1, 2020

7. Frischtak, C., \& Belluzo, L. (2014). Produçao de Commodities e Desenvolvimento Econômico: Uma Introducao. In L. Belluzo, C. Frischtak, \& M. Laplane (Eds.), Produçao de Commodities e Desenvolvimento Econômico. Campinas: Institute of Economics, UNICAMP.

8. Gaulier, G., \& Zignago, S. (2010). BACl: International Trade Database at the Product Level. In CEPII Working Paper No. 2010-23. Paris: CEPII.

9. Hausmann, R., \& Rigobon, R. (2002). An Alternative Interpretation of the "Resource Curse": Theory and Policy Implications. In NBER Working Paper 9424. Cambridge, MA: NBER.

10. Higgins, M., \& Williamson, J. G. (1999). Explaining Inequality the World Round: Cohort Size, Kuznets Curve, and Openness. In NBER Working Paper 7224. Cambridge, MA: NBER.

11. Kindleberger, C. (1962). Foreign Trade and National Economy. New Haven and London: Yale University Press.

12. Lall, S. (2000). The Technological Structure and Performance of Developing Countries Manufactured Exports, 1985-98. Oxford Development Studies, 28(3), 337-369.

13. Maloney, W. F. (2007). Missed Opportunities: Innovation and Resource-based Growth in Latin America. In D. Lederman \& W. F. Maloney (Eds.), Natural Resources. Neither Curse nor Destiny. Washington, DC: The World Bank.

14. Pérez, C. (2010). Technological dynamism and social inclusion in Latin America: a productive development strategy based on natural resources. CEPAL Review(100), 121-141.

15. Prebisch, R. (1949). El desarrollo económico de América Latina y algunos de sus principales problemas. In Comisión Económica para América Latina y el Caribe (Ed.), Estudio Económico de la América Latina, 1948. Santiago de Chile: CEPAL. 
16. Ramos, J. (1998). A development strategy founded on natural resource-based production clusters. CEPAL Review (66), 105-127.

17. Rosser, A. (2006). The Political Economy of the Resource Curse: A Literature Review. In IDS Working Paper 268. Sussex: Institute of Development Studies, University of Sussex.

18. Sachs, J. D., \& Warner, A. M. (1997). Natural Resource Abundance and Economic Growth. In NBER Working Paper 5398. Cambridge, MA: NBER.

19. Sachs, J. D., \& Warner, A. M. (2001). The Curse of Natural Resources. European Economic Review, 45(4-6), 827-838.

20. Senghaas, D. (1985). Aprender de Europa. Barcelona: Editorial Alfa.

21. Smith, A. (1977). An Inquiry into the Nature and Causes of the Wealth of Nations. Chicago: University of Chicago Press.

22. United Nations Conference on Trade and Development (UNCTAD). (2020). UNCTADstat. Data Center. Retrieved from https://unctadstat.unctad.org/wds/ReportFolders/reportFolders.aspx? sCS_ChosenLang=en. Retrieved August 4, 2020

23. Wang, T., Muller, D. B., \& Graedel, T. E. (2007). Forging the Anthropogenic Iron Cycle. Environmental Science \& Technology, 41(14), 5120-5129.

24. Wood, A., \& Berge, K. (1997). Exporting Manufactures: Human Resources, Natural Resources and Trade Policy. The Journal of Development Studies, 34(1), 33-59.

25. Wright, G., \& Czelusta, J. (2007). Resource-based Growth. Past and Present. In D. Lederman \& W. F. Maloney (Eds.), Natural Resources. Neither Curse nor Destiny. Washington, DC: The World Bank.

\section{Figures}




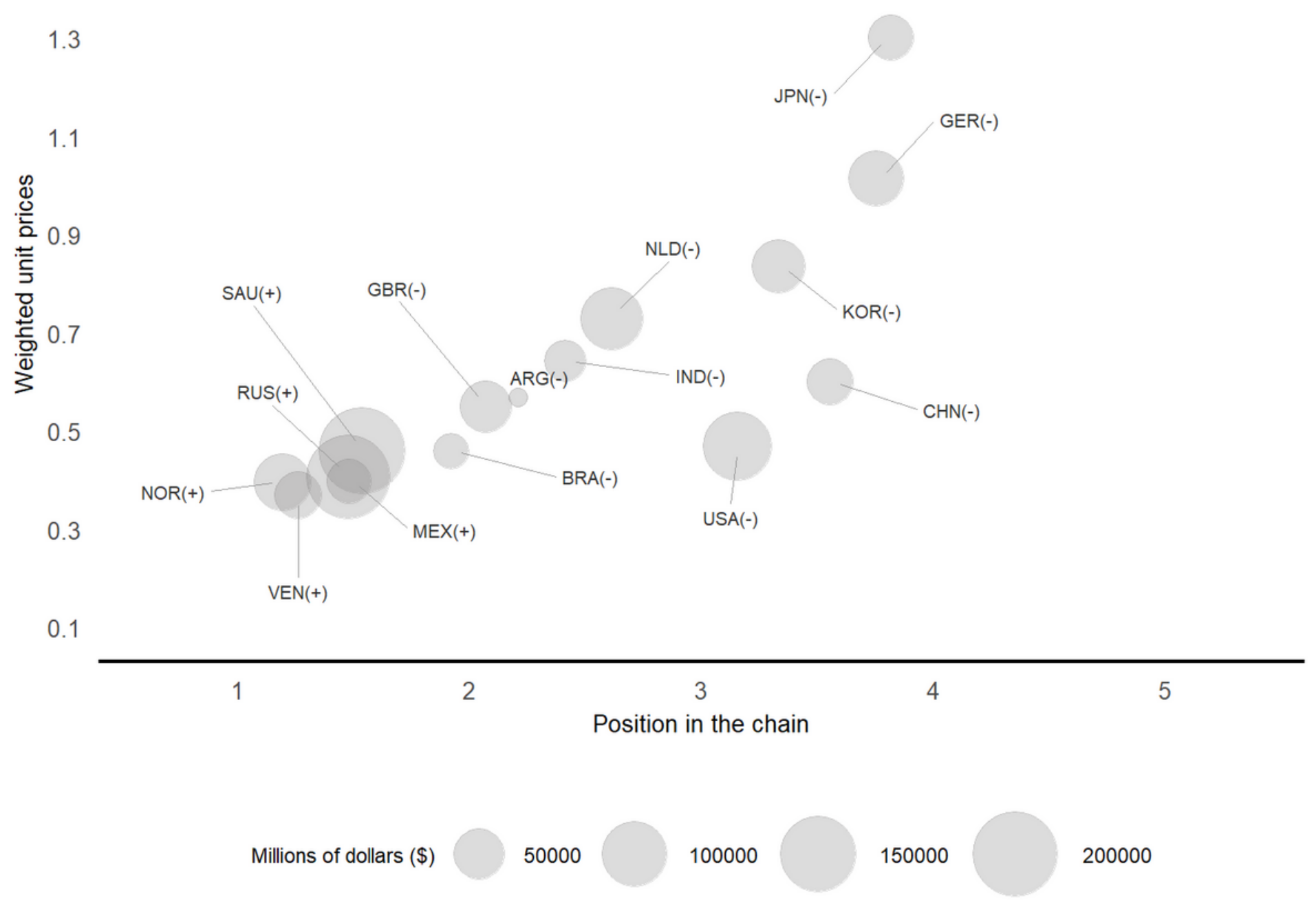

\section{Figure 1}

Unit price and position of selected countries in the petrochemicals chain (average 2007, 2010 and 2016 ; dollars per kilogram and position index) 


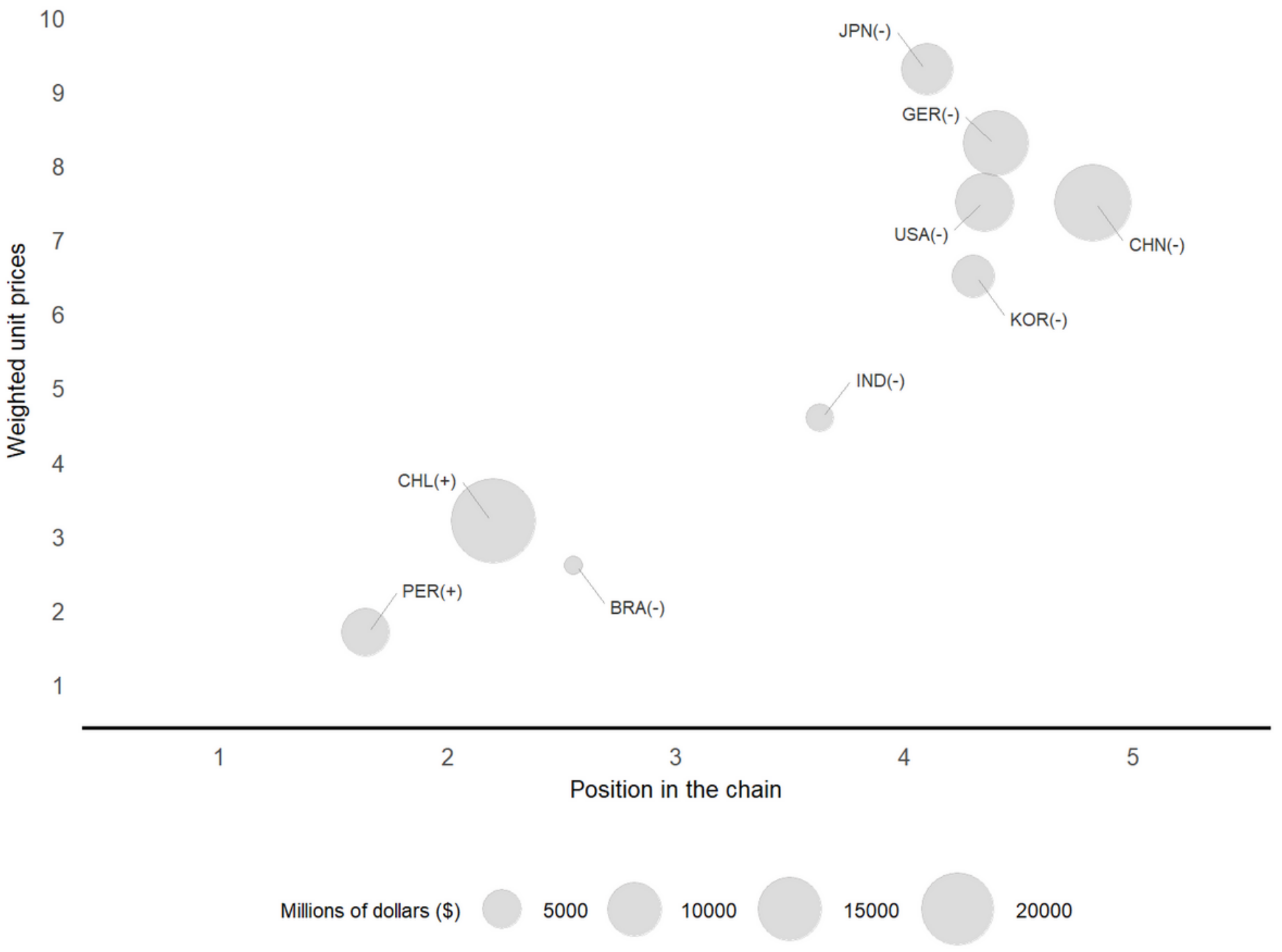

\section{Figure 2}

Unit price and position of selected countries in the copper chain (average 2005, 2010, and 2016; dollars per kilogram and position index) 


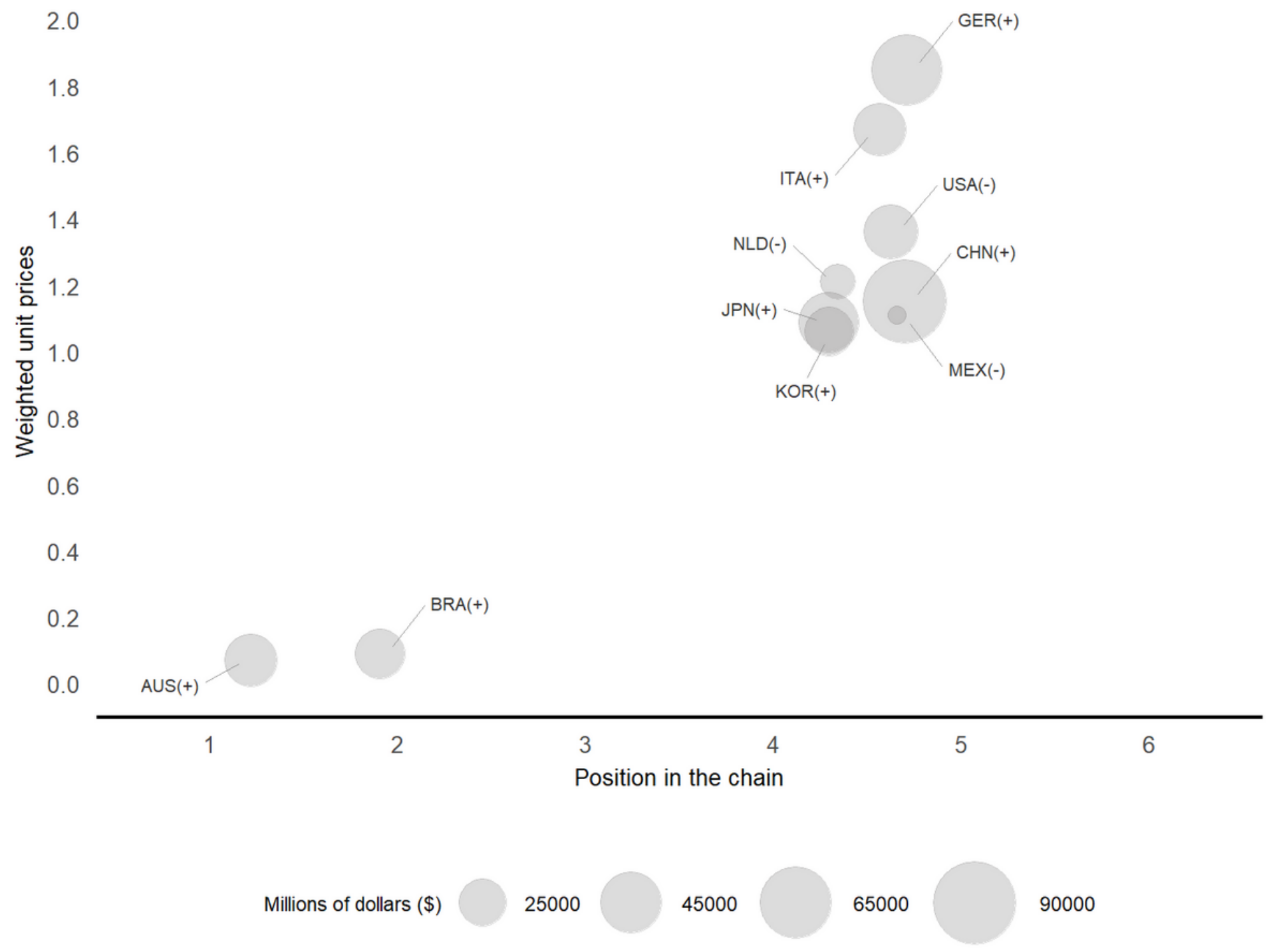

\section{Figure 3}

Unit price and position of selected countries in the iron-steel chain (average 2005, 2010, and 2016; dollars per kilogram and position index) 

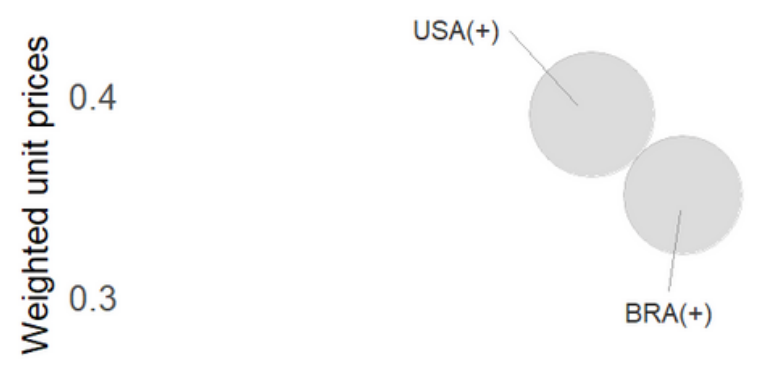

$\mathrm{CHN}(-)$

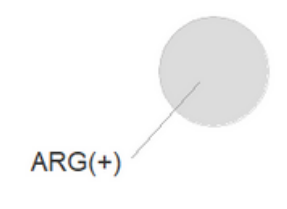

0.2

0.1

1

.

2

Position in the chain
3

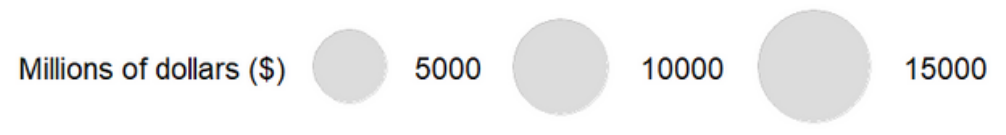

\section{Figure 4}

Unit price and position of selected countries in the soybean chain (average 2005, 2010, and 2016; dollars per kilogram and position index)

\section{Supplementary Files}

This is a list of supplementary files associated with this preprint. Click to download.

- OnlineAppendixA1forreview.docx

- OnlineAppendixA2forreview.docx 